\title{
PARENT-CHILD RELATIONSHIPS AND THE FORMATION OF THE PERSONALITY OF CHILDREN FROM MIGRANT FAMILIES
}

\author{
Ekaterina Klimova \\ Post-graduate student, Penza State University (Russia)
}

\begin{abstract}
The paper contains the results of a theoretical analysis of the problem of the influence of parent-child relationships on the formation of a child's personality. The main factors that activate the personal development of children in a situation of socio-psychological adaptation are described. The results of an empirical study related to the diagnosis of the image of the mother in children from migrant families are presented. The paper shows that the image of the mother is an important factor in the formation of the child's personality, an indicator of his or her success in socio-psychological interactions. It is empirically proven that the interaction with the mother in preschool children with a positive image of the Self is distinguished by emotional closeness and harmonious contacts. In its turn, the interaction with the mother in preschool children with a negative image of the Self is characterized by the ambivalence of manifestations, a restrained, disharmonious background of contacts. It is noted that these characteristics of parent-child relationships are the basic stimulus for the formation of the ideas of the Self and significant Others in preschool children.
\end{abstract}

Keywords: Migrant children, parent-child relationships, self-image, personality of the child.

\section{Introduction}

The problem of parent-child relationships is relevant regardless of time. The variety of conceptual studies allows us to suggest that parent-child relationships affect the child's self-awareness in the process of education. Undoubtedly, this problem is acute in the families of migrants since the unstable situation in the new society of parents is reflected in the socio-psychological well-being of their children.

The problem of migration of children and adults are studied by many Russian scientists. Thus, V.V. Konstantinov, E.V. Ryaguzova, R.M. Shamionov studied in their research the social tension in society and the specifics of the socio-psychological adaptation of adults and children in a new multicultural space.

The formation of the child's image of the Self and his or her self-consciousness is influenced by the peculiarities of upbringing, early relations of the mother and the child, personal characteristics of parents, recurring family conflicts, psychological problems of the child associated with family problems, the adaptation to new sociocultural changes in another society.

A. Freud singled out the relations between the child and the parents as the main source of the child's development. She pointed out that the child's experiences influence his or her development Frejd, (1990). A similar point of view was expressed by C. Jung. The scientist believed that the mental state of the child depends on the unconscious reactions of the parents Yung, (1994). In this connection, it is interesting to mention the point of view of E. Erikson who noted the role of social reality in the development of the child's personality Erikson, (1996).

The emotional aspect of the manifestation of parental love was considered by E. Fromm. The scientist believed that parental love acts as an activating component in the development of a personality Fromm, (1992). A similar point of view can be found in the research of D. Bowlby. The scientist came to the conclusion that the child's affection is accompanied by a need for protection and safety, and helps him or her successfully adapt to society Boulbi, (1996).

Thus, Western conceptual research is based on the fact that parental attitude and behavior have a strong influence on the formation of a child's self-awareness and, thus, on his or her successful socio-psychological adaptation in society. This can be especially acute in migrant families. This is due to the fact that migrants undergo pronounced changes in their lifestyle which entails a shortage of the resources of emotional and personal interaction.

Russian researchers consider both parent-child interaction and the identity of the parent affecting the development of the child. So, A.K. Rubchenko believes that parent-child relationships should be 
considered through the phenomenon of maternal and paternal "instinct", the image of the Self, Self-concept and personal characteristics Rubchenko, (2005). According to O.A. Karabanova, the formation of a child's personality is influenced by the following parameters Karabanova, (2004).: the specificity of emotional connections; the degree of involvement of subjects in parent-child relationships; meeting the needs of the child; a style of communication with the child; the resolution of problem situations; social control; the degree of consistency in family upbringing.

Thus, the data obtained during the analysis of the studies allows us to state that the personal characteristics of parents, their relationship to the child largely determines the dynamics of the development of the child's personality.

In this connection, we suggested that the context of parent-child relationships, in particular the image of the mother, affects the formation of the personality of the preschool child, his or her self-attitude and the attitude towards significant Others.

We conducted a study to confirm the hypothesis. The respondents were preschool children from migrant families who attend preschool institutions.

\section{Methods}

As preparatory work using projective techniques, we studied the personal characteristics of children, on the basis of which we divided children into two groups: children with a positive image of the Self, and children with a negative image of the Self.

For diagnosing the children under test, the projective methodology "A drawing of a child (mother) in the image of an animal" in the modification of I.S. Chegina according to the "Drawing a Family" methodology in the interpretation of T. Zinkevich-Evstigneeva, D. Kudzilova. The respondents were 270 children of senior preschool age (120 boys and 150 girls).

. The drawings were analyzed by the quantitative method of mathematical statistics (the Pearson chi-square) and the qualitative method (Table 1).

\section{Results}

Table 1. Statistical verification (a drawing of the mother in the image of an animal) using the Pearson chi-square.

\begin{tabular}{|l|l|l|l|l|l|l|}
\hline $\begin{array}{l}\text { The image of } \\
\text { a child's Self }\end{array}$ & $\begin{array}{l}\text { The aesthetics } \\
\text { of the image }\end{array}$ & $\begin{array}{l}\text { The location of } \\
\text { image }\end{array}$ & $\begin{array}{l}\text { The decoration } \\
\text { of the image }\end{array}$ & $\begin{array}{l}\text { Generic } \\
\text { assignment }\end{array}$ & $\begin{array}{l}\text { Emotional } \\
\text { attitude }\end{array}$ \\
\hline $\begin{array}{l}\text { The positive } \\
\text { image of a } \\
\text { child's Self }\end{array}$ & $\mathrm{x}^{2}$-value & 7,385 & 22,615 & 37,385 & 59,769 & 0,462 \\
\hline & p-value & $\mathbf{0 , 0 0 7}$ & $\mathbf{0 , 0 1 9}$ & $\mathbf{0 , 0 0 3}$ & $\mathbf{0 , 0 0 3}$ & 0,497 \\
\hline $\begin{array}{l}\text { The negative } \\
\text { image of a } \\
\text { child's Self }\end{array}$ & $\mathrm{x}^{2}$-value & 29,727 & 24,818 & 59,182 & 16,636 & 37,909 \\
\hline & $\mathrm{p}$-value & $\mathbf{0 , 0 2 5}$ & $\mathbf{0 , 0 2 6}$ & $\mathbf{0 , 0 0 5}$ & $\mathbf{0 , 0 0 4}$ & $\mathbf{0 , 0 0 7}$ \\
\hline
\end{tabular}

The children with a positive image of the Self drew figures with clear details in the association of the image of the mother. In most of them, the animal images are distinguished by high aesthetics of the image, good drawing of details and parts of the image as well as the proportionality of the figure of the depicted animal with the sheet area, which is confirmed by the high level of statistical significance ( $\mathrm{p} \leq 0.001)$ according to all the considered criteria. In the characteristics of the authors all the images of animals are called by diminutive and affectionate names (for example, a butterfly - "Laska", a butterfly "Zvyozdochka", a kitty - "Liza", etc.).

From the children's stories it also follows that the depicted animals have extremely warm emotions and feelings for the children (for example, "... loves to praise me", "loves me very much"). The listed characteristics in this case indicate full emotional acceptance by the child of his or her mother, as well as the harmony of child-mother relationships. According to the generic assignment, the drawn animals can be attributed to both the class of domestic and the one of predatory, wild animals. The description traces the change in the emotional background of the mood in relation to the depicted animal from positive to neutral and vice versa. In the description of an animal's disposition, positive characteristics are often replaced by negative ones (for example, "likes to have fun ... gets angry when somebody prevents it from doing... etc.). The descriptions contain answers to the questions asked in the instructions.

The listed characteristics in this case indicate the child's emotional acceptance of their mother, however, it is not possible to say about the complete harmony of mother and child relations since the above 
mismatches in the drawings or descriptions of the animals by children may indicate the existence of psychological prohibitions or some emotional distancing in parent-child relationships.

The children with the negative image of the Self depicted the animals with missing details. The sizes of the figures are mostly small. There are a lot of drawings in which the animals are located below the centre of the leaf. The listed indicators were confirmed by a high level of statistical significance (at $\mathrm{p} \leq 0.001$ ). According to the generic assignment, the drawn animals can be attributed to both the class of domestic animals and the one of predatory and wild animals.

In the characteristics of the authors the depicted images are often called by the names of their domestic animals (for example, a cat - "Vasya"), as well as by fictitious names (a grass-snake - "Bogdan"). There is often ignoring the question of the name ("this panther will be called ... Panther", “... I don't know what to call it!"). A similar fact may indicate that the children practically do not identify the resulting image of the animal with the image of the mother, and therefore do not call the animal her name. The descriptions, as a rule, are short, monosyllabic, not fully revealing the characteristics of the mores and habits of the animals. The emotional attitude in the children towards the image is most often neutral, however, negative statements are not excluded.

In the characteristics the descriptions of the animal's actions are more prevailing than its qualities and properties ("... likes to watch TV", “... scolds when my brother and I are bullies"). It is important to note that in the group of the children with the negative image of the Self, in contrast to the other group of the children, there are violations of the instructions, i.e. the children instead of representing and drawing the image of the animal drew the image of a person. Such a mismatch in this case may indicate either the presence of psychological prohibitions in the relationship of the child with the mother, or the authoritarian position of the mother in the parent-child relationship, which does not allow the child to depict or even present the mother in a different way.

Thus, it can be stated that the nature of parent-child relationships is expressed in the collective image of parents, in particular the image of the mother and acts as an indicator of the well-being / dysfunction of the child's personal development, his or attitude to the world and his or her own self. This characteristic is especially characteristic of the rooted ideas of the positive / negative images of the mother in children of migrants in the situations of socio-psychological adaptation.

\section{Conclusion}

The educational impact of the mother on the child is one of the most important components of the maternal relationship revealing the features of the disciplining foundation in family education through the measurement of key indicators. Mothers in the groups of preschool-age children with different specific characteristics of the image of the Self it has their own characteristics:

- in the group of the children with a positive image of the Self it is distinguished by gentleness, emotional closeness in relations with a child, acceptance of his or her personal qualities and behavioural manifestations.

- in the group of the children with a negative image of the Self the maternal attitude manifests itself as not sufficiently harmonious, which is a serious destabilizing factor in the development of the child's personality.

\section{References}

Boulbi, D. (1996). Privyazannost'. Per. s angl. [pod. obshch. red. G.V. Burmenskoj]. M.: Gardariki, 2003. $477 \mathrm{~s}$.

Erikson, E.G. (1996). Detstvo i obshchestvo: per. s angl. SPb.: Lenato, AST, Fond «Universitetskaya kniga», $592 \mathrm{~s}$.

Frejd, A. (1990). Norma i patologiya detskogo razvitiya. Per. s nem. YA.L. Obuhova. M., 200 s.

Fromm E. (1992). Dusha cheloveka. M.: Respublika, $430 \mathrm{~s}$.

Karabanova, O.A. (2004). Psihologiya semejnyh otnoshenij i osnovy semejnogo konsul'tirovaniya: Uchebnoe posobie. M.: Gardariki, $320 \mathrm{~s}$.

Konstantinov, V.V. (2018). Social'no-psihologicheskaya adaptaciya migrantov: teoriya i empiricheskie issledovaniya. Moskva: PERO, $236 \mathrm{~s}$.

Rubchenko, A.K. (2005). Problema detsko-roditel'skih otnoshenij v zarubezhnoj psihologii // Psiholog v detskom sadu. №2. S.84 - 98 .

Ryaguzova, E.V., Shamionov R.M. (2010). Psihologiya riska/sbornik statej «Vvedenie v social'nuyu riskologiyu». Saratov, izd-vo IC «Nauka», S. 74-93.

Yung, K. (1994). Analiticheskaya psihologiya. Per. s nem. SPb.: Kentavr, 136 s. 